\title{
25. RECONNAISSANCE SPORE AND POLLEN EXAMINATION, EARLY TERTIARY TURBIDITE BEDS, ALEUTIAN ABYSSAL PLAIN, SITE 183
}

Jack A. Wolfe, U. S. Geological Survey, Menlo Park, California

\begin{abstract}
Samples submitted for a determination of spore-pollen content were processed with the standard treatment of acids and heavy liquid flotation. All samples except one from Core 29 contained some pollen and spores, although most samples were sparse. Two fossiliferous lower (?) Oligocene samples ${ }^{1}$ from Sections 2 and 3 of Core 28 were particularly sparse; both Pinus and Picea were present. The lower (?) Oligocene samples from Cores 31 and 32 were also not especially productive; noted were Picea, Pinus, Tsuga, Alnus, Fagus, and Ericales. A sample from Core 35, which is of middle or late Eocene age, contained the best
\end{abstract}

\footnotetext{
${ }^{1}$ Ages reported here are based on nannofossil assemblages.
}

preserved assemblage; the sample is dominated by conifers particularly Picea, Pinus, Tsuga, and Cedrus(?). The middle or upper Eocene sample from Core 36 does not contain as much pollen as Sample 35, but a more diverse flora is represented, including Abies, Picea, Cedrus(?), Pterocarya, Alnus, Betula, Fagus, and Quercus(?). The one Eocene sample from Core 37 contained only a sparse representation of both Pinaceae and broad-leaved plants.

These pollen floras are generally similar to those known from approximately isochronous beds on the Alaskan mainland. Particularly significant is the fact that the late Eocene sample is dominated by Pinaceae, as are the lower (?) Oligocene samples. Approximately isochronous samples from Washington and Oregon typically have few members of Pinaceae (except for the ubiquitous Pinus). 